\title{
Evolution of the Phenolic Content and Extractability Indices During Ripening of Nebbiolo Grapes from the Piedmont Growing Areas over Six Consecutive Years
}

\author{
E. Cagnasso, F. Torchio, V. Gerbi, S. Río Segade, S. Giacosa, L. Rolle* \\ Di.Va.P.R.A. - Microbiology and Food Technology Sector, University of Turin, Via L. da Vinci 44, 10095 Grugliasco (TO), \\ Italy
}

Submitted for publication: April 2011

Accepted for publication: May 2011

Key words: ripening, vintage, anthocyanins, flavonoids, phenol extractability indices, red grapes

\begin{abstract}
The phenolic composition and extractability indices of grape berries play a key role in assessing red wine quality because the relationship between grape phenolic maturity and wine phenolic composition is well known. In this work, grape quality indices were determined in Nebbiolo grapes from two growing areas of Langhe (South Piedmont), at different stages throughout the ripening process in six consecutive years (2004 to 2009), with the aim of evaluating the ripening- and growing area-related changes in the grape indices separately. The effect of vintage was also investigated. Ripeness data were compared with analogous data determined in Nebbiolo grapes grown in the Carema area (North Piedmont). The vintage effect far outweighed any changes in the grape indices introduced by the ripening stage, even those arising from differences in the production area. In the Langhe and Carema zones, the average berry mass, pH, total acidity, total anthocyanins extractable at pH 3.2, total flavonoids and non-anthocyanin flavonoids extractable at $\mathrm{pH} 1$, and the seed maturity index were seasonally dependent. The more ripening-affected parameters were the technological ones. This work highlights the importance of determining the phenol extractability, since it provides relevant information that allows improved management of the maceration stage.
\end{abstract}

\section{INTRODUCTION}

Phenolic compounds play an important role in the quality of red wine, as they contribute to certain sensory characteristics, particularly colour and astringency. Anthocyanins are the principal phenolic compounds responsible for the colour in red grapes and young wines, and they are located in berry skins (Mateus et al., 2002; Revilla et al., 2009). On the other hand, grape seeds are rich in proanthocyanidins, which strongly influence wine bitterness and astringency (Vidal et al., 2004). Moreover, anthocyanins can react with other phenolic compounds and microbial metabolites to produce more stable pigments, resulting in a colour change from the bluish-red of young wines to the reddish-brown of mature wines, and in a decrease in wine astringency (Boulton, 2001; Cheynier et al., 2006; Fulcrand et al., 2006).

The concentration of polyphenols in grape berries depends on the grapevine variety and is influenced by viticultural and environmental factors (Failla et al., 2004; Downey et al., 2006; Guidoni et al., 2008; Vacca et al., 2009). These compounds are extracted from grapes into the wine during the maceration-fermentation step and, hence, the winemaking technique affects the wine composition (Sacchi et al., 2005). In spite of the changes that occur in phenolic compounds during the maceration step, it is possible to predict the wine colour from the grape polyphenols (Cagnasso et al., 2008; González-Neves et al., 2010; Zanoni et al., 2010).

Anthocyanins are gradually accumulated in berry skins, from véraison through grape ripening, with malvidin-3-Oglucoside being the most abundant anthocyanin in almost all red grape varieties (Ryan \& Revilla, 2003; Cholet \& Darné, 2004). Moreover, Nebbiolo grapes are characterised by a higher content of di-substituted anthocyanins on the B-ring, in particular peonidin-3-O-glucoside, which is higher than that of malvidin-3-O-glucoside (Mattivi et al., 2006). However, the anthocyanin concentration may decrease in overripe grapes (Fournand et al., 2006). Proanthocyanidins are accumulated mainly in berry skins before véraison, achieving their highest concentration in the seeds at véraison. From this moment, seed proanthocyanidins decline slowly until close to grape ripeness, but thereafter they remain relatively constant (Kennedy et al., 2000).

The full exploitation of the grape potential reached in the vineyard requires correct management of the winemaking process, particularly the maceration-fermentation stage. The wine industry has turned its attention to assess the anthocyanin extractability (Saint-Cricq et al., 1998a; Romero-Cascales et al., 2005), since grapes rich in anthocyanins at harvest 
do not usually produce highly coloured wines. Therefore, the need for knowing the tendency of the berry skin to yield up anthocyanins is evident (Ortega-Regules et al., 2006). Nevertheless, their extraction efficiency from the grape berry into the must/wine also depends on the grape anthocyanin profile, as some authors have reported lower extraction yields for coumaroylated anthocyanins (Fournand et al., 2006). Furthermore, the anthocyanin extractability varies throughout grape ripening as a consequence of the compositional changes that occur in the cell wall of the skin during its degradation by pectolytic enzymes (RomeroCascales et al., 2005; Ortega-Regules et al., 2006). In seeds, the histological and histochemical modifications that occur during fruit development also affect the ability to release phenols (Vidal et al., 2002; Mattivi et al., 2009).

Regarding the assessment of the phenolic compound extractability, it is strongly influenced by the extraction method used (Saint-Cricq et al., 1998b; Romero-Cascales et al., 2005; Cagnasso et al., 2008; Kontoudakis et al., 2010). In this sense, the cellular maturity index or extractability index (EA) defined by Glories and Augustin (1993) seems to provide an adequate robustness to predict phenolic compounds in the resulting wines (Romero-Cascales et al., 2005; Cagnasso et al., 2008; Kontoudakis et al., 2010).

Most of the works published on the accumulation of phenolic compounds throughout grape ripening, as well as on their ease of extraction under normal maceration conditions, have reported results corresponding to only a few years. In this work, the chemical parameters involved in the phenolic ripeness of Nebbiolo grapes, one of the most important and well-known Italian vine varieties, were determined throughout the grape ripening process during six consecutive years in two different growing areas in Langhe, a zone where the big reds such as Barolo and Barbaresco DOCG wines are produced (South Piedmont, Northwest Italy). Furthermore, at harvest, the same parameters were compared with the analogous ones determined in Nebbiolo grapes growing in the Carema area located in North Piedmont. The long period of observation permitted an evaluation of the influence of the stage of grape ripeness and growing location on the variability of these chemical parameters.

\section{MATERIALS AND METHODS \\ Grape samples}

Grape samples of the Nebbiolo red cultivar (Vitis vinifera L.) were collected at different physiological stages from two typical vineyards located in the Barbaresco DOCG (area I) and from two vineyards in the Barolo DOCG (area II) (South Piedmont) during six consecutive years (2004 to 2009). In the same vintages, other samples were collected at grape harvest in four typical vineyards in the Carema DOC (area III) (North Piedmont). For each sampling, 1200 grape berries were randomly picked with pedicels attached. In the different years, the samples were collected at different times during grape ripening: $\mathrm{A}=29$ August, $\mathrm{B}=5-10$ September, $\mathrm{C}=12$ 17 September, $\mathrm{D}=18$-24 September, $\mathrm{E}=27$ September-1 October, $\mathrm{F}=5-8$ October, $\mathrm{G}=12-13$ October. The last sample for each vineyard corresponds to the grape harvest date. One subsample of 600 berries was used to determine the phenol content and extractability indices ( 200 berries for repetition). The remaining berries were partitioned into three subsamples and used for determining standard physicochemical parameters in the grape must obtained by manual crushing and centrifugation.

\section{Technological parameters}

Total soluble solids ( ${ }^{\circ}$ Brix) and volumic mass were determined by using an Anton Paar electronic densimeter Model DMA 5000 (Graz, Austria). The pH and total acidity were determined according to International Organisation of Vine and Wine methods (OIV, 2008).

\section{Phenol content and extractability indices}

The phenol extractability indices were assessed in accordance with the procedure proposed by Glories and Augustin (1993), and Saint-Cricq et al. (1998b), which was slightly modified for Nebbiolo grapes by Cagnasso et al. (2008). The spectrophotometric measurements were performed using an UV-1601PC spectrophotometer (Shimazdu Scientific Instruments Inc., Columbia, MD, USA). Three replicates of 200 grape berries were used. The following parameters were determined in solutions at both $\mathrm{pH} 1$ and $\mathrm{pH}$ 3.2: total anthocyanins (A1 and A3.2), total flavonoids (TF1 and TF3.2) and non-anthocyanin flavonoids (FNA1 and FNA3.2) (Di Stefano \& Cravero, 1991; Cagnasso et al., 2008). Total anthocyanins were expressed as malvidin-3-glucoside chloride, while total flavonoids and non-anthocyanin flavonoids were expressed as $(+)$-catechin. The total phenolic content in the extract at pH 3.2 (absorbance at $280 \mathrm{~nm}$, A280) was determined according to Ribéreau-Gayon (1970). The relative standard deviations of the phenolic compound determinations, based on repeated analyses $(n=20)$ of the sample extracts, were 1.14 and $0.93 \%$ for A1-A3.2 and TF1TF3.2 respectively (Torchio et al., 2010).

The cellular maturity index (EA) and the seed maturity index $(\mathrm{Mp})$ were calculated as follows (Romero-Cascales et al., 2005; Cagnasso et al., 2008; González-Neves et al., 2010):

$\mathrm{EA}(\%)=[(\mathrm{A} 1-\mathrm{A} 3.2) / \mathrm{A} 1] \times 100$

$\operatorname{Mp}(\%)=[(\mathrm{A} 280-((\mathrm{A} 3.2 / 1000) \times \mathrm{TAR})) / \mathrm{A} 280] \times 100$

The average ratio (TAR) between total phenols (A280) and total anthocyanins in the grape skins was 70 for A3.2, expressed as g/L (Cagnasso et al., 2008).

\section{Statistical analysis}

Statistical analyses were performed using the statistical software package SPSS (version 17.0; SPSS Inc., Chicago, IL, USA). Tukey-b test for $p<0.05$ was used in order to establish statistical differences by one-way analysis of variance (ANOVA).

\section{RESULTS AND DISCUSSION}

Table 1 shows the evolution of the technological parameters throughout grape ripening during the observed period in Langhe, where two different growing areas (I and II) were studied. The total soluble solid, $\mathrm{pH}$ and total acidity values confirm that the grape samples collected weekly differed in sugar content and acidity, because the two first parameters increased throughout the grape ripening process and the last one decreased. In spite of the fact that the differences 
TABLE 1

Evolution of technological parameters for Nebbiolo grapes through grape ripening during six consecutive years (2004-2009) in two different Langhe growing areas (I and II)

\begin{tabular}{|c|c|c|c|c|c|}
\hline Year & $\begin{array}{c}\text { Growing } \\
\text { area }\end{array}$ & $\begin{array}{c}\text { Ripening } \\
\text { stage }^{1} \\
\end{array}$ & $\begin{array}{c}\text { Total soluble } \\
\text { solids }^{2} \\
\end{array}$ & $\mathrm{pH}$ & Total acidity ${ }^{3}$ \\
\hline \multirow{7}{*}{2004} & \multirow{6}{*}{ I } & $\mathrm{B}$ & $22.20 \pm 0.42 a, \alpha$ & $2.88 \pm 0.07 \mathrm{a}, \alpha$ & $9.5 \pm 0.8 \mathrm{a}, \alpha$ \\
\hline & & $\mathrm{C}$ & $22.75 \pm 0.21 \mathrm{a}, \alpha$ & $2.98 \pm 0.04 \mathrm{ab}, \alpha$ & $7.7 \pm 0.4 b, \alpha$ \\
\hline & & $\mathrm{D}$ & $24.15 \pm 0.21 b, \alpha$ & $3.04 \pm 0.06 \mathrm{ab}, \alpha$ & $7.8 \pm 0.4 \mathrm{~b}, \alpha$ \\
\hline & & $\mathrm{E}$ & $24.70 \pm 0.28 b, \alpha$ & $3.06 \pm 0.07 \mathrm{ab}, \alpha$ & $7.3 \pm 0.4 b, \alpha$ \\
\hline & & $\mathrm{F}$ & $24.80 \pm 0.42 b, \alpha$ & $3.12 \pm 0.06 b, \alpha$ & $7.2 \pm 0.3 b, \alpha$ \\
\hline & & $\mathrm{G}$ & $24.55 \pm 0.07 \mathrm{~b}, \alpha$ & $3.14 \pm 0.02 b, \alpha$ & $6.3 \pm 0.1 b, \alpha$ \\
\hline & $\operatorname{Sign}^{\mathrm{a}}$ & & $* * *$ & $*$ & $* *$ \\
\hline \multirow{8}{*}{2004} & \multirow{6}{*}{ II } & B & $21.05 \pm 1.20 \mathrm{a}, \alpha$ & $2.82 \pm 0.03 \mathrm{a}, \alpha$ & $9.9 \pm 0.4 \mathrm{a}, \alpha$ \\
\hline & & $\mathrm{C}$ & $21.80 \pm 0.14 \mathrm{ab}, \beta$ & $2.93 \pm 0.05 \mathrm{ab}, \alpha$ & $8.3 \pm 0.5 b, \alpha$ \\
\hline & & $\mathrm{D}$ & $23.05 \pm 0.78 \mathrm{ab}, \alpha$ & $3.02 \pm 0.05 \mathrm{~b}, \alpha$ & $7.5 \pm 0.3 \mathrm{bc}, \alpha$ \\
\hline & & $\mathrm{E}$ & $24.20 \pm 0.71 b, \alpha$ & $3.00 \pm 0.07 b, \alpha$ & $7.9 \pm 0.4 b c, \alpha$ \\
\hline & & $\mathrm{F}$ & $23.85 \pm 0.49 \mathrm{ab}, \alpha$ & $3.09 \pm 0.05 b, \alpha$ & $7.0 \pm 0.4 b c, \alpha$ \\
\hline & & $\mathrm{G}$ & $23.40 \pm 0.71 \mathrm{ab}, \alpha$ & $3.09 \pm 0.03 b, \alpha$ & $6.6 \pm 0.2 c, \alpha$ \\
\hline & $\operatorname{Sign}^{\mathrm{a}}$ & & $*$ & $* *$ & $* * *$ \\
\hline & $\operatorname{Sign}^{\mathrm{b}}$ & & $*(\mathrm{C}), \mathrm{ns}(\mathrm{B}, \mathrm{D}-\mathrm{G})$ & ns (B-G) & ns (B-G) \\
\hline \multirow{4}{*}{2005} & & $\mathrm{C}$ & $23.80 \pm 0.28 \mathrm{a}, \alpha$ & $2.96 \pm 0.01 \mathrm{a}, \alpha$ & $7.8 \pm 0.2 \mathrm{a}, \alpha$ \\
\hline & I & $\mathrm{D}$ & $23.60 \pm 0.57 \mathrm{a}, \alpha$ & $2.99 \pm 0.02 \mathrm{a}, \alpha$ & $7.5 \pm 0.6 \mathrm{a}, \alpha$ \\
\hline & & $\mathrm{E}$ & $24.85 \pm 0.49 \mathrm{a}, \alpha$ & $3.06 \pm 0.06 \mathrm{a}, \alpha$ & $6.8 \pm 0.0 \mathrm{a}, \alpha$ \\
\hline & $\operatorname{Sign}^{\mathrm{a}}$ & & ns & ns & ns \\
\hline \multirow{6}{*}{2005} & \multirow{4}{*}{ II } & $\mathrm{B}$ & $22.85 \pm 1.34 \mathrm{a}, \alpha$ & $2.96 \pm 0.06 \mathrm{a}, \alpha$ & $8.3 \pm 0.2 \mathrm{a}, \alpha$ \\
\hline & & $\mathrm{C}$ & $22.95 \pm 1.63 \mathrm{a}, \alpha$ & $2.96 \pm 0.01 \mathrm{a}, \alpha$ & $7.5 \pm 0.2 b, \alpha$ \\
\hline & & $\mathrm{D}$ & $23.35 \pm 1.48 \mathrm{a}, \alpha$ & $3.00 \pm 0.02 \mathrm{a}, \alpha$ & $7.3 \pm 0.2 b, \alpha$ \\
\hline & & $\mathrm{E}$ & $24.05 \pm 1.06 \mathrm{a}, \alpha$ & $3.03 \pm 0.01 \mathrm{a}, \alpha$ & $6.7 \pm 0.2 b, \alpha$ \\
\hline & $\operatorname{Sign}^{\mathrm{a}}$ & & $\mathrm{ns}$ & $\mathrm{ns}$ & $* *$ \\
\hline & $\operatorname{Sign}^{\mathrm{b}}$ & & ns $(C-E)$ & ns $(C-E)$ & ns $(C-E)$ \\
\hline \multirow{5}{*}{2006} & \multirow{4}{*}{ I } & $\mathrm{B}$ & $23.15 \pm 0.49 \mathrm{a}, \alpha$ & $2.85 \pm 0.01 \mathrm{a}, \alpha$ & $9.8 \pm 0.3 \mathrm{a}, \alpha$ \\
\hline & & $\mathrm{C}$ & $24.25 \pm 0.35 a, \alpha$ & $2.95 \pm 0.01 b, \alpha$ & $8.8 \pm 0.2 \mathrm{ab}, \alpha$ \\
\hline & & $\mathrm{D}$ & $24.22 \pm 0.47 a, \alpha$ & $3.01 \pm 0.01 \mathrm{c}, \alpha$ & $7.8 \pm 0.6 \mathrm{bc}, \alpha$ \\
\hline & & $\mathrm{E}$ & $24.33 \pm 0.69 \mathrm{a}, \alpha$ & $3.09 \pm 0.01 \mathrm{~d}, \alpha$ & $7.0 \pm 0.3 c, \alpha$ \\
\hline & $\operatorname{Sign}^{\mathrm{a}}$ & & $\mathrm{ns}$ & $* * *$ & $* *$ \\
\hline \multirow{6}{*}{2006} & \multirow{4}{*}{ II } & $\mathrm{B}$ & $23.88 \pm 0.11 \mathrm{a}, \alpha$ & $2.88 \pm 0.08 \mathrm{a}, \alpha$ & $8.8 \pm 0.3 \mathrm{a}, \alpha$ \\
\hline & & $\mathrm{C}$ & $24.42 \pm 0.25 \mathrm{a}, \alpha$ & $2.95 \pm 0.03 \mathrm{a}, \alpha$ & $7.9 \pm 0.0 \mathrm{~b}, \beta$ \\
\hline & & $\mathrm{D}$ & $24.44 \pm 0.05 a, \alpha$ & $3.05 \pm 0.09 \mathrm{a}, \alpha$ & $6.8 \pm 0.3 c, \alpha$ \\
\hline & & $\mathrm{E}$ & $24.39 \pm 0.06 \mathrm{a}, \alpha$ & $3.06 \pm 0.09 \mathrm{a}, \alpha$ & $6.7 \pm 0.4 c, \alpha$ \\
\hline & $\operatorname{Sign}^{\mathrm{a}}$ & & ns & $\mathrm{ns}$ & $* *$ \\
\hline & $\operatorname{Sign}^{\mathrm{b}}$ & & ns (B-D) & ns (B-D) & $*(\mathrm{C}), \mathrm{ns}(\mathrm{B}, \mathrm{D})$ \\
\hline \multirow{5}{*}{2007} & \multirow{4}{*}{ I } & $\mathrm{A}$ & $21.96 \pm 1.82 \mathrm{a}, \alpha$ & $2.88 \pm 0.06 \mathrm{a}, \alpha$ & $9.5 \pm 0.2 \mathrm{a}, \alpha$ \\
\hline & & B & $23.31 \pm 1.06 \mathrm{a}, \alpha$ & $2.95 \pm 0.08 \mathrm{a}, \alpha$ & $8.7 \pm 0.7 \mathrm{a}, \alpha$ \\
\hline & & $\mathrm{C}$ & $24.34 \pm 1.07 \mathrm{a}, \alpha$ & $3.00 \pm 0.11 \mathrm{a}, \alpha$ & $8.4 \pm 1.1 \mathrm{a}, \alpha$ \\
\hline & & $\mathrm{D}$ & $24.67 \pm 0.42 \mathrm{a}, \alpha$ & $3.08 \pm 0.13 \mathrm{a}, \alpha$ & $8.1 \pm 1.2 \mathrm{a}, \alpha$ \\
\hline & $\operatorname{Sign}^{\mathrm{a}}$ & & ns & ns & ns \\
\hline \multirow{6}{*}{2007} & \multirow{4}{*}{ II } & $\mathrm{A}$ & $22.56 \pm 1.49 \mathrm{a}, \alpha$ & $2.90 \pm 0.06 \mathrm{a}, \alpha$ & $8.5 \pm 0.1 \mathrm{a}, \beta$ \\
\hline & & B & $23.40 \pm 1.70 \mathrm{a}, \alpha$ & $2.99 \pm 0.09 \mathrm{a}, \alpha$ & $7.8 \pm 0.1 b, \alpha$ \\
\hline & & $\mathrm{C}$ & $24.73 \pm 1.73 a, \alpha$ & $3.03 \pm 0.04 \mathrm{a}, \alpha$ & $7.6 \pm 0.1 b, \alpha$ \\
\hline & & $\mathrm{D}$ & $25.72 \pm 1.33 \mathrm{a}, \alpha$ & $3.10 \pm 0.01 \mathrm{a}, \alpha$ & $7.1 \pm 0.1 \mathrm{c}, \alpha$ \\
\hline & $\operatorname{Sign}^{\mathrm{a}}$ & & ns & $\mathrm{ns}$ & $* *$ \\
\hline & $\operatorname{Sign}^{\mathrm{b}}$ & & ns (A-D) & ns (A-D) & $*(\mathrm{~A}), \mathrm{ns}(\mathrm{B}-\mathrm{D})$ \\
\hline
\end{tabular}


TABLE 1 (CONTINUED)

\begin{tabular}{|c|c|c|c|c|c|}
\hline Year & $\begin{array}{c}\text { Growing } \\
\text { area }\end{array}$ & $\begin{array}{l}\text { Ripening } \\
\text { stage }^{1}\end{array}$ & $\begin{array}{c}\text { Total soluble } \\
\text { solids }^{2}\end{array}$ & $\mathrm{pH}$ & Total acidity ${ }^{3}$ \\
\hline \multirow{6}{*}{2008} & \multirow{5}{*}{ I } & B & $22.17 \pm 1.17 \mathrm{a}, \alpha$ & $2.87 \pm 0.06 \mathrm{a}, \alpha$ & $9.1 \pm 0.7 \mathrm{a}, \alpha$ \\
\hline & & $\mathrm{C}$ & $23.92 \pm 0.06 \mathrm{ab}, \alpha$ & $3.00 \pm 0.04 \mathrm{ab}, \alpha$ & $7.9 \pm 0.7 \mathrm{a}, \alpha$ \\
\hline & & $\mathrm{D}$ & $24.50 \pm 0.01 b c, \alpha$ & $3.01 \pm 0.02 \mathrm{ab}, \alpha$ & $7.6 \pm 0.1 \mathrm{a}, \alpha$ \\
\hline & & $\mathrm{E}$ & $25.10 \pm 0.21 b c, \alpha$ & $3.01 \pm 0.03 \mathrm{ab}, \alpha$ & $7.5 \pm 0.3 \mathrm{a}, \alpha$ \\
\hline & & $\mathrm{F}$ & $26.09 \pm 0.11 \mathrm{c}, \alpha$ & $3.10 \pm 0.04 b, \alpha$ & $7.2 \pm 0.0 \mathrm{a}, \alpha$ \\
\hline & $\operatorname{Sign}^{\mathrm{a}}$ & & $* *$ & $*$ & ns \\
\hline \multirow{6}{*}{2008} & \multirow{4}{*}{ II } & $\mathrm{B}$ & $23.97 \pm 0.04 \mathrm{a}, \alpha$ & $2.92 \pm 0.07 \mathrm{a}, \alpha$ & $8.9 \pm 0.4 \mathrm{a}, \alpha$ \\
\hline & & $\mathrm{C}$ & $24.12 \pm 0.45 \mathrm{a}, \alpha$ & $3.00 \pm 0.01 \mathrm{a}, \alpha$ & $7.9 \pm 1.0 \mathrm{a}, \alpha$ \\
\hline & & $\mathrm{D}$ & $24.60 \pm 0.18 \mathrm{ab}, \alpha$ & $2.98 \pm 0.05 \mathrm{a}, \alpha$ & $7.8 \pm 0.1 \mathrm{a}, \alpha$ \\
\hline & & $\mathrm{E}$ & $25.26 \pm 0.30 \mathrm{~b}, \alpha$ & $3.04 \pm 0.02 \mathrm{a}, \alpha$ & $7.3 \pm 0.2 \mathrm{a}, \alpha$ \\
\hline & Sign $^{\mathrm{a}}$ & & $*$ & $\mathrm{~ns}$ & $\mathrm{~ns}$ \\
\hline & $\operatorname{Sign}^{\mathrm{b}}$ & & ns (B-E) & ns (B-E) & ns (B-E) \\
\hline \multirow{5}{*}{2009} & \multirow{4}{*}{ I } & B & $24.80 \pm 0.14 \mathrm{a}, \alpha$ & $3.11 \pm 0.04 \mathrm{a}, \alpha$ & $7.3 \pm 0.5 \mathrm{a}, \alpha$ \\
\hline & & $\mathrm{C}$ & $25.50 \pm 0.16 b, \alpha$ & $3.22 \pm 0.14 \mathrm{a}, \alpha$ & $6.5 \pm 0.6 \mathrm{a}, \alpha$ \\
\hline & & $\mathrm{D}$ & $25.16 \pm 0.08 \mathrm{ab}, \alpha$ & $3.21 \pm 0.11 \mathrm{a}, \alpha$ & $6.2 \pm 0.4 \mathrm{a}, \alpha$ \\
\hline & & $\mathrm{E}$ & $26.00 \pm 0.14 c, \alpha$ & $3.25 \pm 0.09 a, \alpha$ & $6.2 \pm 0.4 a, \alpha$ \\
\hline & $\operatorname{Sign}^{\mathrm{a}}$ & & $* *$ & $\mathrm{~ns}$ & ns \\
\hline \multirow{6}{*}{2009} & \multirow{4}{*}{ II } & $\mathrm{B}$ & $24.35 \pm 0.64 a, \alpha$ & $3.10 \pm 0.01 \mathrm{a}, \alpha$ & $7.2 \pm 0.4 \mathrm{a}, \alpha$ \\
\hline & & $\mathrm{C}$ & $24.60 \pm 1.61 \mathrm{a}, \alpha$ & $3.14 \pm 0.01 \mathrm{ab}, \alpha$ & $6.4 \pm 0.2 \mathrm{a}, \alpha$ \\
\hline & & $\mathrm{D}$ & $24.94 \pm 0.87 \mathrm{a}, \alpha$ & $3.18 \pm 0.04 \mathrm{ab}, \alpha$ & $6.2 \pm 0.0 \mathrm{a}, \alpha$ \\
\hline & & $\mathrm{E}$ & $24.75 \pm 1.07 \mathrm{a}, \alpha$ & $3.24 \pm 0.04 b, \alpha$ & $6.0 \pm 0.4 \mathrm{a}, \alpha$ \\
\hline & $\operatorname{Sign}^{\mathrm{a}}$ & & ns & $*$ & $\mathrm{~ns}$ \\
\hline & $\operatorname{Sign}^{b}$ & & ns (B-E) & ns (B-E) & ns $(\mathrm{B}-\mathrm{E})$ \\
\hline
\end{tabular}

${ }^{1}$ Ripening stages are $\mathrm{A}=29$ August, $\mathrm{B}=5-10$ September, $\mathrm{C}=12-17$ September, $\mathrm{D}=18$-24 September, $\mathrm{E}=27 \mathrm{September}-1$ October, $\mathrm{F}=5-8$ October, $\mathrm{G}=12-13$ October; ${ }^{2}{ }^{\mathrm{o}} \mathrm{Brix} ;{ }^{3} \mathrm{~g} / \mathrm{L}$ tartaric acid. All data are expressed as average value \pm standard deviation $(\mathrm{n}=3)$. Different Latin letters within the same column indicate significant differences ${ }^{(a)}$ among several ripening stages in the same growing area (Tukey-b test; $p<0.05)$. Different Greek letters within the same column indicate significant differences $\left({ }^{b}\right)$ among growing areas at the same ripening stage (Tukey-b test; $\mathrm{p}<0.05$ ). ${ }^{*}, * *, * * *$ and ns indicate significance at $\mathrm{p}<0.05,0.01,0.001$ and not significant respectively.

found were not always significant, particularly in the years 2005 and 2007, the evolution of the standard parameters that define technological maturity can be monitored clearly during ripening. The soluble solid content, expressed as ${ }^{\circ}$ Brix, indicates that a good technological maturity was achieved at harvest for all the years and production areas studied. Furthermore, the values obtained for the technological parameters corresponded to those usually found for the Nebbiolo cultivar in both production areas (I and II) (Cagnasso et al., 2008; Guidoni et al., 2008). No significant changes were observed for the technological parameters in Nebbiolo grapes sampled at the same date in the two different production areas considered, with some partial exceptions for ${ }^{\circ}$ Brix in 2004, and for the total acidity in 2006 and 2007. This suggests a small grape variability in the technological parameters in the Langhe zone related to the constant production yields registered in the different years $(7.5$ to $8.0 \mathrm{t} / \mathrm{ha})$ in accordance with the "Disciplinary of Production" of Barolo and Barbaresco wines.

The evolution of the phenolic composition and phenol extractability indices during grape ripening in two growing areas (I and II), belonging to the Langhe zone, in the years 2004 to 2009, is shown in Table 2. With very few exceptions, the results obtained indicate that the phenolic maturity parameters were similar among the grape berries sampled weekly in each growing area and year. Guidoni et al. (2008) reported that total anthocyanin accumulation in Nebbiolo grapes started rapidly at véraison, with an increasing trend until 45 days post-véraison, but no further accumulation was detected in 2000. These last authors also confirmed that, in 2001, total anthocyanin concentration did not increase from 30 to 56 days post-véraison. Therefore, the monitoring of the anthocyanin content during the last weeks of grape ripening is not adequate for the selection of the harvest date for the Nebbiolo variety.

The results obtained agreed with the findings of Ryan and Revilla (2003) for Cabernet Sauvignon and Tempranillo grapes, which reached the maximum anthocyanin accumulation when the sugar content in the grape juice was 191 to $245 \mathrm{~g} / \mathrm{L}$ (19.9 to $24.6^{\circ} \mathrm{Brix}$ ). It agreed with the highest values for the anthocyanin content found in these two grape varieties for soluble solid contents, expressed as ${ }^{\circ} \mathrm{Brix}$, of 22.2 

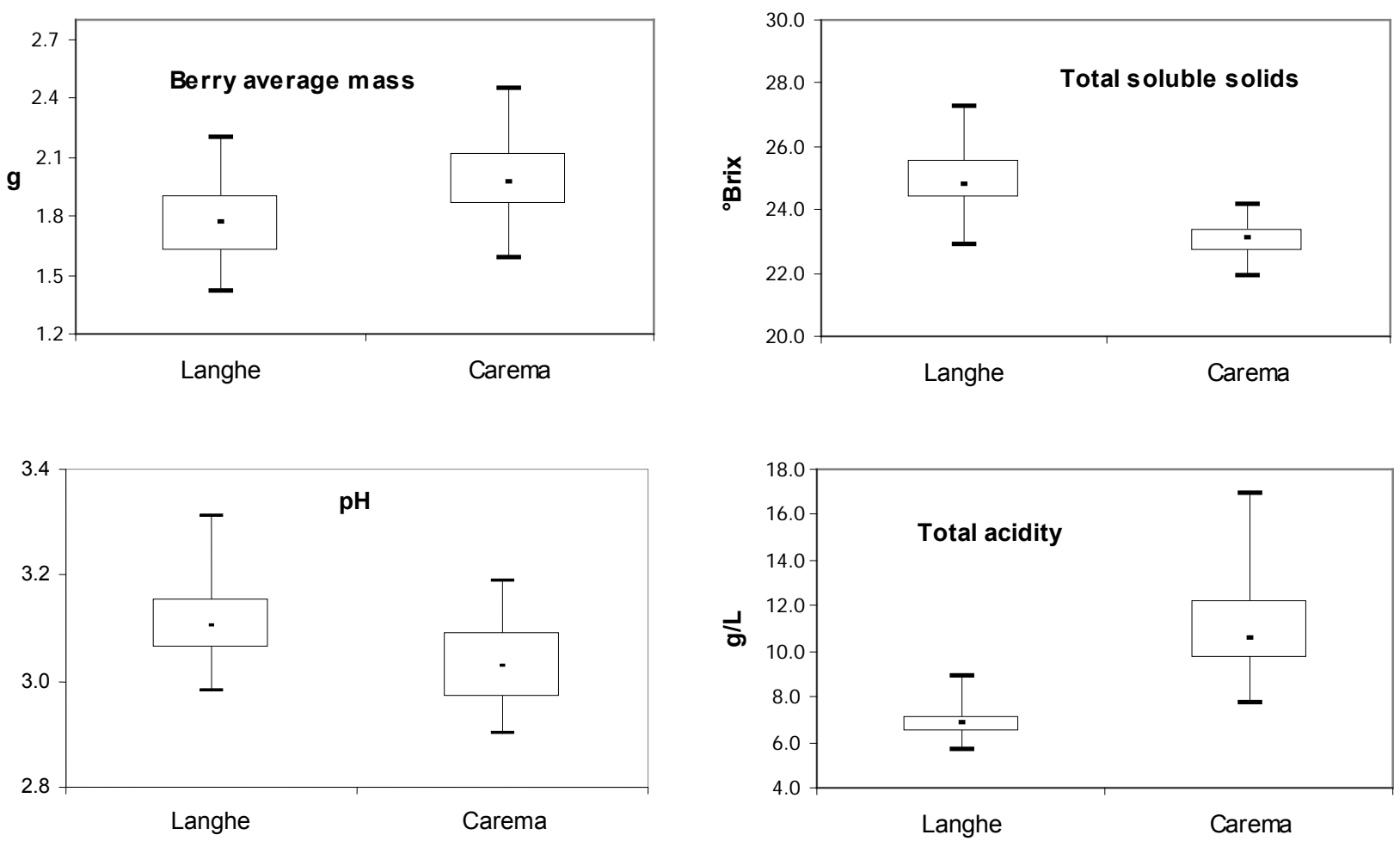

FIGURE 1

Box-plot of technological parameters of Nebbiolo grapes at harvest in two different Piedmont growing areas (Langhe and Carema), using four samples per area in six consecutive years (2004-2009).

and 19.4 respectively (Navarro et al., 2008). Furthermore, the higher anthocyanin concentration in Monastrell grapes was reported for soluble solid contents comprising between 20.4 and $24.0^{\circ}$ Brix (De la Hera Orts et al., 2005). Fournand et al. (2006) also suggested that total red pigments in Shiraz grapes remained nearly unchanged from $20.8^{\circ}$ Brix. On the other hand, Mateus et al. (2002) observed fluctuations in the anthocyanin monoglucoside content in Touriga nacional and Touriga francesa varieties during the last month of ripening.

In relation to the evolution of total polyphenols during grape ripening, the maximum accumulation was reached when the soluble solid content was higher than $19.4^{\circ} \mathrm{Brix}$ for the Bobal, Tempranillo, Cabernet Sauvignon and Crujidera varieties (Navarro et al., 2008).

Regarding the evolution of EA during ripening, it is particularly striking to note the opposite patterns observed for different grape varieties. Some authors have suggested that berry ripening favours an increase in anthocyanin extractability (Saint-Criq et al., 1998b; Glories, 1999), as it can be deduced from the progressive and significant decrease observed in EA, while our results show the trend described by González-Neves et al. (2002) and Romero-Cascales et al. (2005), who indicated that the sugar content changed with no significant changes in this index.

No important decrease in Mp was observed for Nebbiolo grapes, in disagreement with the decreases reported for Galician varieties (Northwest Spain) during the last month of ripening, particularly for the most coloured grapes (Río Segade et al., 2008).
The monitoring of the phenolic maturity parameters during ripening did not permit the selection of the harvest date for Nebbiolo grapes in any areas studied. On the other hand, no significant changes were observed for these parameters in Nebbiolo grapes sampled at the same date in the two different production areas considered, with some partial exceptions for EA in 2004 and 2006, and for FNA3.2 in 2004. This suggests a small grape variability in the phenolic maturity parameters in the Langhe zone.

At harvest, the total anthocyanin content (A1 and A3.2) varied from 473 to $756 \mathrm{mg} / \mathrm{kg}$ and from 274 to $434 \mathrm{mg} / \mathrm{kg}$ of berries (as malvidin-3-glucoside chloride) respectively. On the other hand, total flavonoids (TF1 and TF3.2) ranged from 2666 to $3590 \mathrm{mg} / \mathrm{kg}$ and from 1751 to $2217 \mathrm{mg}$ / $\mathrm{kg}$ of berries (as (+)-catechin) respectively, whereas nonanthocyanin flavonoids (FNA1 and FNA3.2) ranged from 1761 to $2582 \mathrm{mg} / \mathrm{kg}$ and from 1233 to $1704 \mathrm{mg} / \mathrm{kg}$ of berries (as (+)-catechin) respectively. The extractability indices EA and Mp varied from 32.2 to $48.3 \%$ and from 42.5 to $68.2 \%$ respectively.

It is important to consider that these values for the phenol content and extractability indices agree with those reported for Nebbiolo grapes in other Langhe vineyards in previous years (Cagnasso et al., 2008). Nevertheless, these last authors found greater values for TF3.2 (2 130 to $3345 \mathrm{mg} / \mathrm{kg}(+)$-catechin), and lower ones for EA (14.3 to $38.1 \%$ ). In particular, the lowest data for EA, showed in the reference, corresponded to those for 2001, when the skin cell walls were more degraded by pectolytic enzymes 

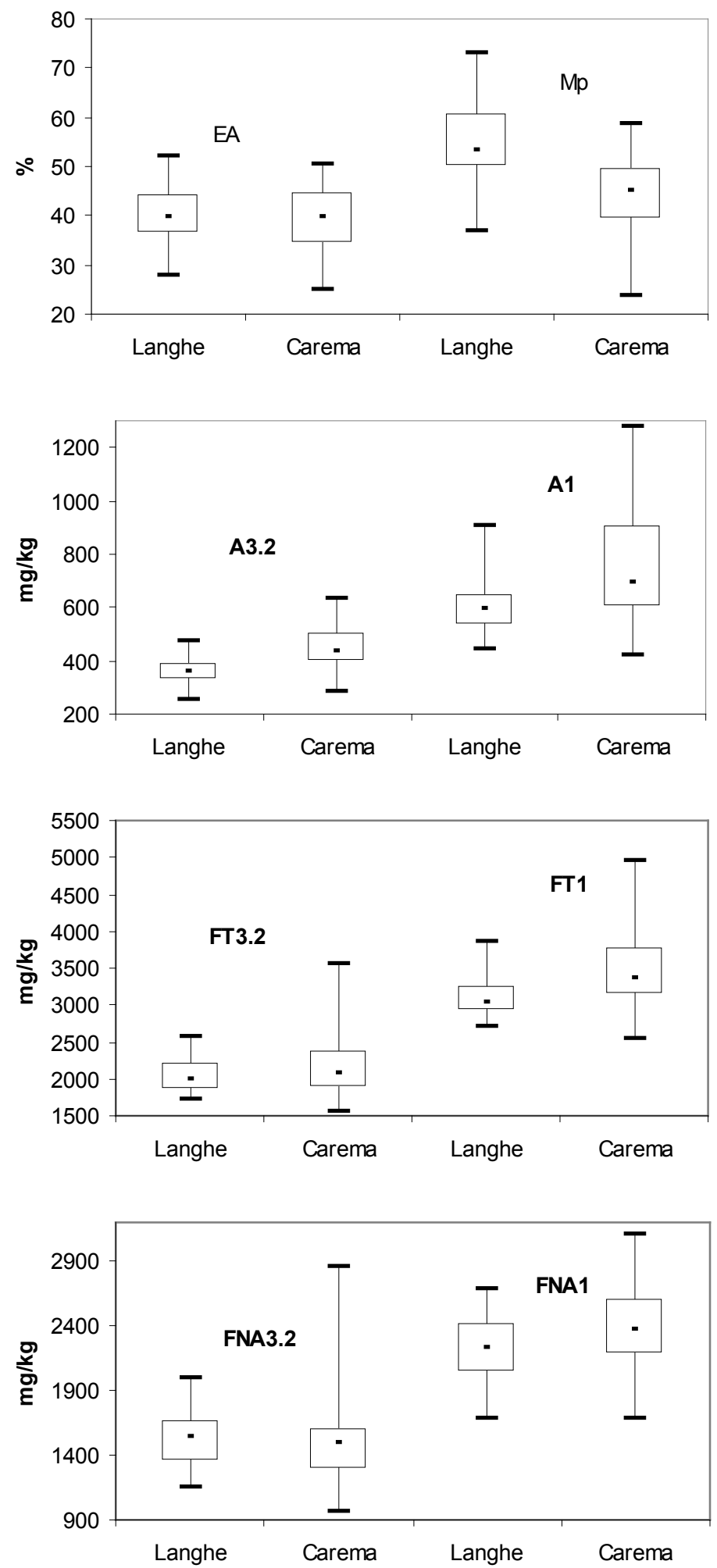

FIGURE 2

Box-plot of phenolic maturity parameters of Nebbiolo grapes at harvest in two different Piedmont growing areas (Langhe and Carema), using four samples per area in six consecutive years (2004-2009). 


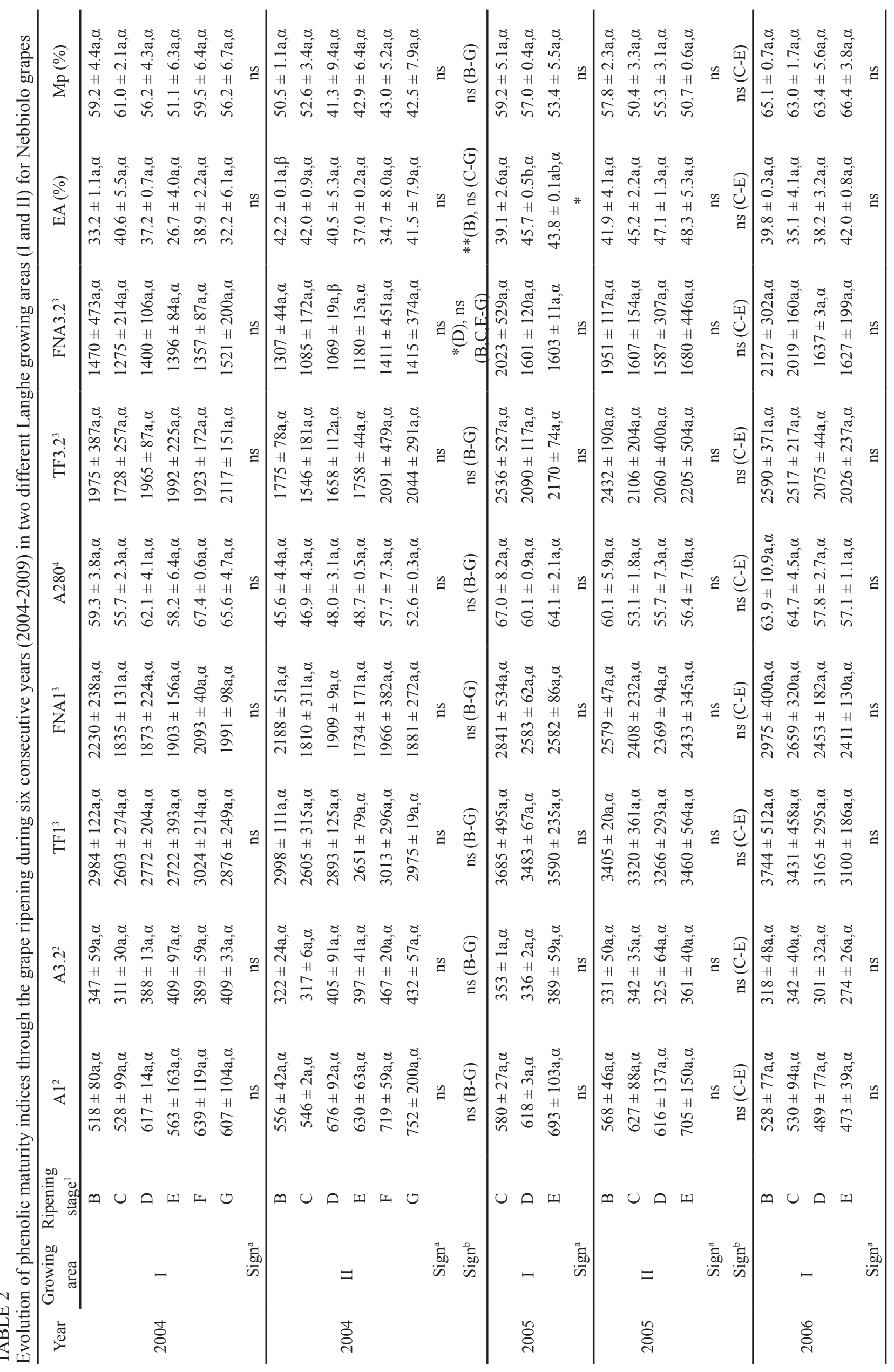




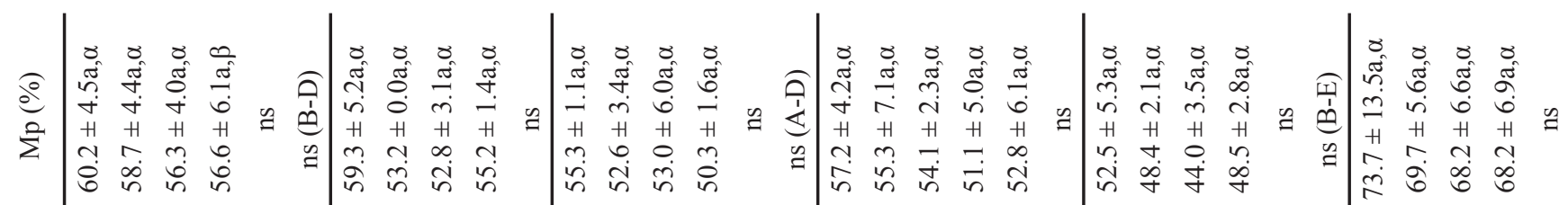

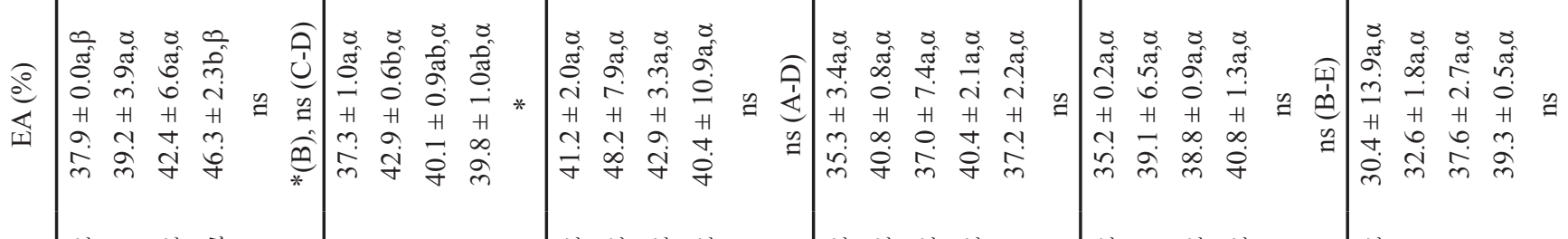

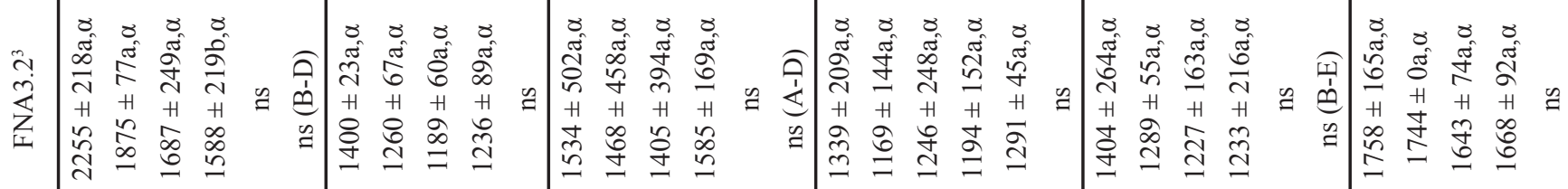

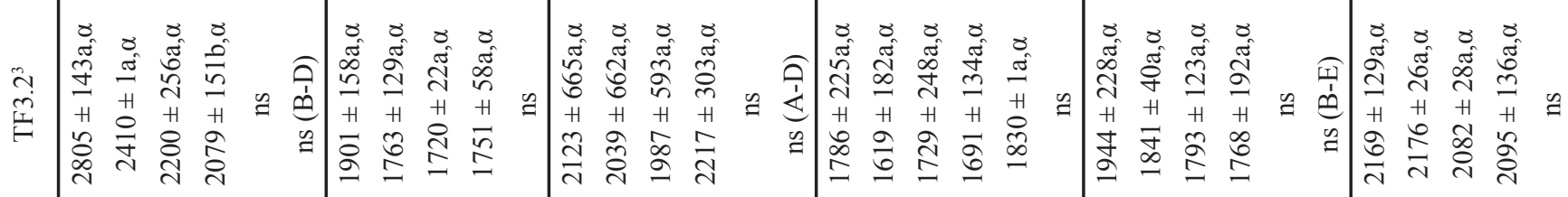

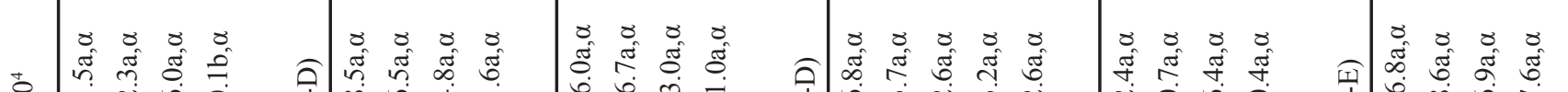

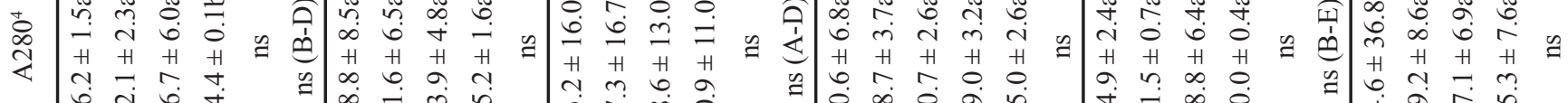

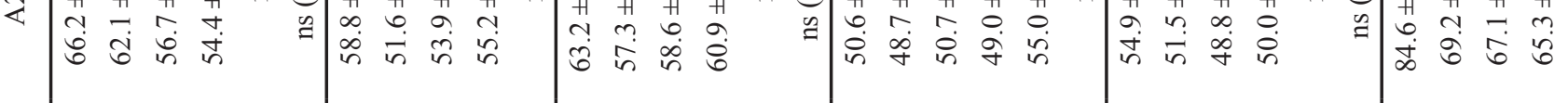

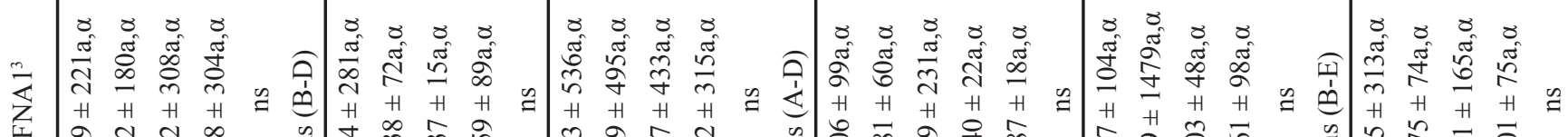

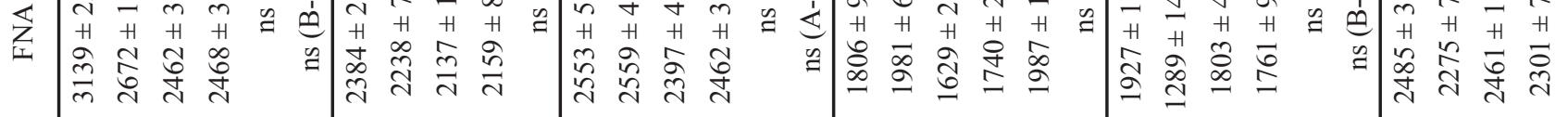

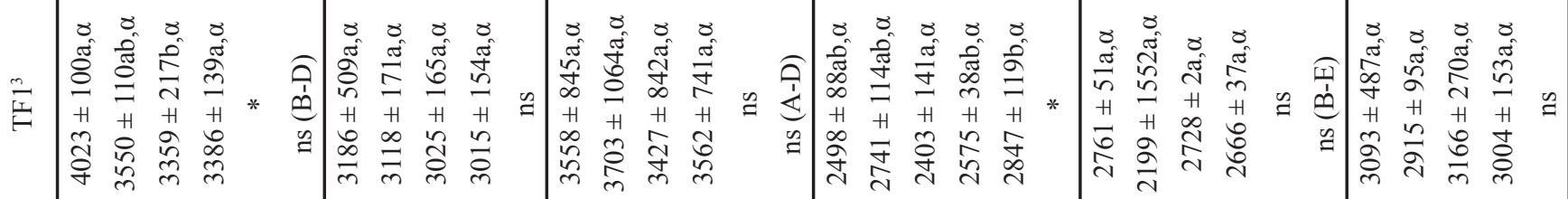

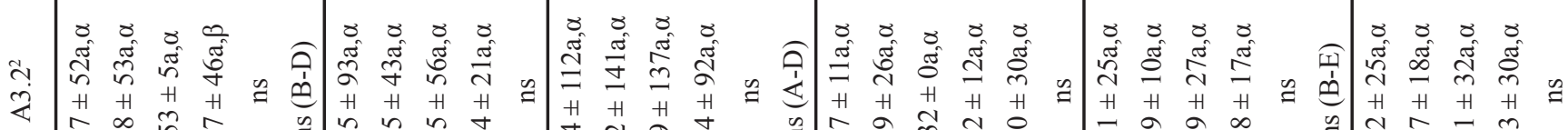

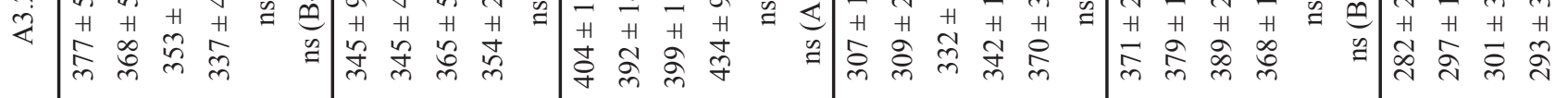

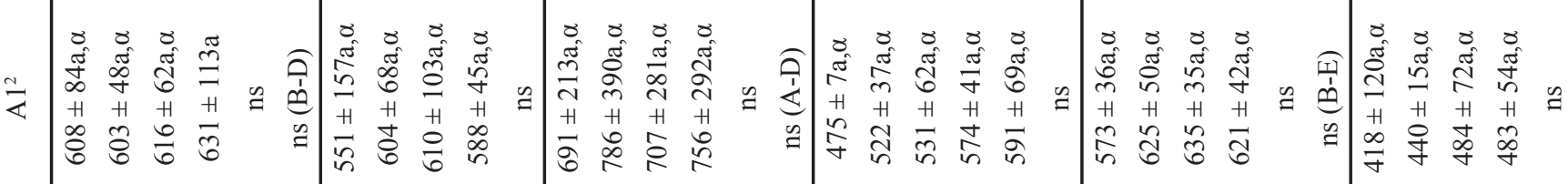

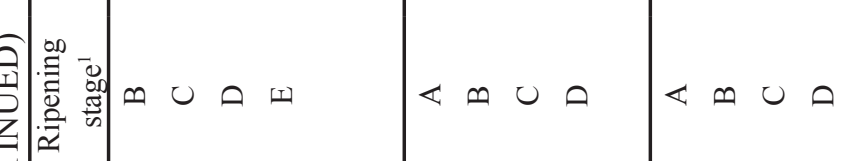




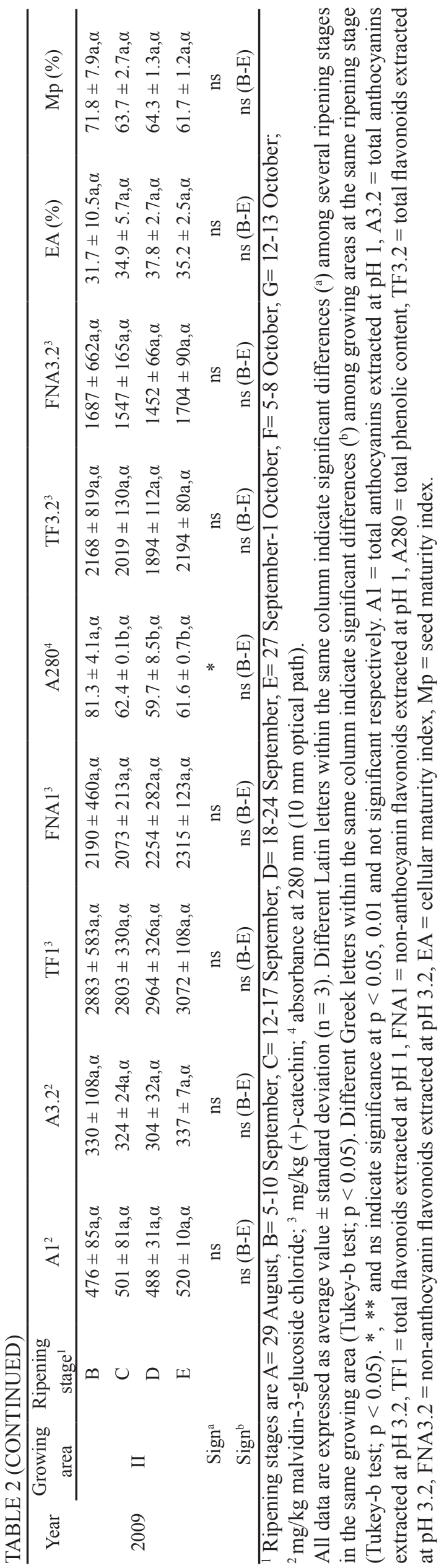

because of Botrytis attack (Ribéreau-Gayon et al., 2004a). Total anthocyanin concentrations comprising between 502 and $714 \mathrm{mg} / \mathrm{kg}$ malvidin-3-glucoside chloride were also published by Guidoni et al. (2008) for Nebbiolo grapes grown in the Langhe zone. Cagnasso et al. (2008) reported lower values for A1, A3.2 and EA in Nebbiolo grapes than in Barbera and Dolcetto from Langhe vineyards, whereas TF1 and TF3.2 were similar or higher in Nebbiolo grapes, with the differences being greater with respect to the Dolcetto variety. These last authors also indicated lower values for $\mathrm{Mp}$ in Nebbiolo grapes, but the average ratio (TAR) between total phenols and anthocyanins in grape skins was 70 for this grape variety instead of the TAR of 40 that is usually used. Other work confirmed the findings in Barbera grapes grown in different Piedmont areas (Torchio et al., 2010), particularly for A1, A3.2 and EA, and reported lower values for FNA1 and FNA3.2 in Barbera grapes than our results obtained in Nebbiolo.

It is important to know the anthocyanin extractability index at harvest, because it provides information about the extraction rate from berry skins into the wine (Cagnasso et al., 2008). The elaboration of high quality red wines, especially from Nebbiolo grapes, requires a good accumulation of anthocyanins in berry skins to obtain a high colour intensity. The anthocyanin extractability also has to be assessed (SaintCricq et al., 1998a; González-Neves et al., 2010) so that the tendency of the berry skin to yield up anthocyanins during the winemaking process can be known (Romero-Cascales et al., 2005; Ortega-Regules et al., 2006). Therefore the phenol extractability indices are key factors in wine grape quality, influencing the winemaking methodology as mentioned above. This aspect is particularly important for grape varieties rich in 3'-hydroxylated anthocyanins, because these pigments, which are extracted preferentially during the initial phase of maceration, may easily be oxidised by the enzymes present in the juice. Those cultivars containing an anthocyanin profile made up mainly of molecules trisubstituted in the B-ring are more protected against oxidation (González-Neves et al., 2008). In fact, a remarkable loss of peonidin-3-glucoside and cyanidin-3-glucoside was noticed during winemaking using Nebbiolo grapes (Cagnasso et al., 2008).

All the technological and phenolic maturity parameters obtained in the Langhe zone (areas I and II) at harvest were compared among years (see Table 3). The highest phenol richness in Nebbiolo grapes was obtained in 2005. The higher values for EA were also associated with 2005, which imply a lower skin cell wall fragility that limits anthocyanin extractability. The greater Mp obtained in 2009 involves a higher contribution of seed tannins and, therefore, incomplete seed maturity. In the Barolo area (II), the differences found were not significant because of the high grape variability between the two vineyards studied. Instead, only total soluble solids, A3.2, FNA1 and EA were dependent on the vintage in the Barbaresco area (I). This confirmed that the genotype is a preponderant factor in the accumulation of phenolic compounds (Ribéreau-Gayon et al., 2004b). Recent works relate the ease of anthocyanin extraction to the chemical composition of the skin cell walls (Ortega-Regules et al., 2006), indicating that this is a varietal characteristic 


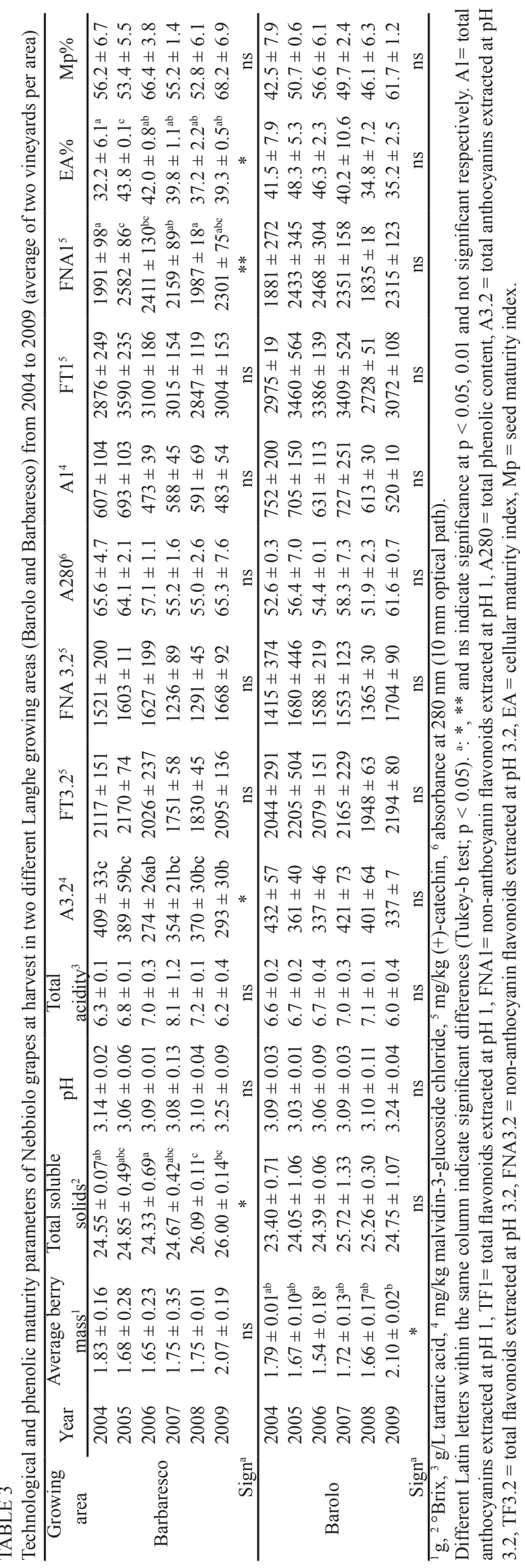

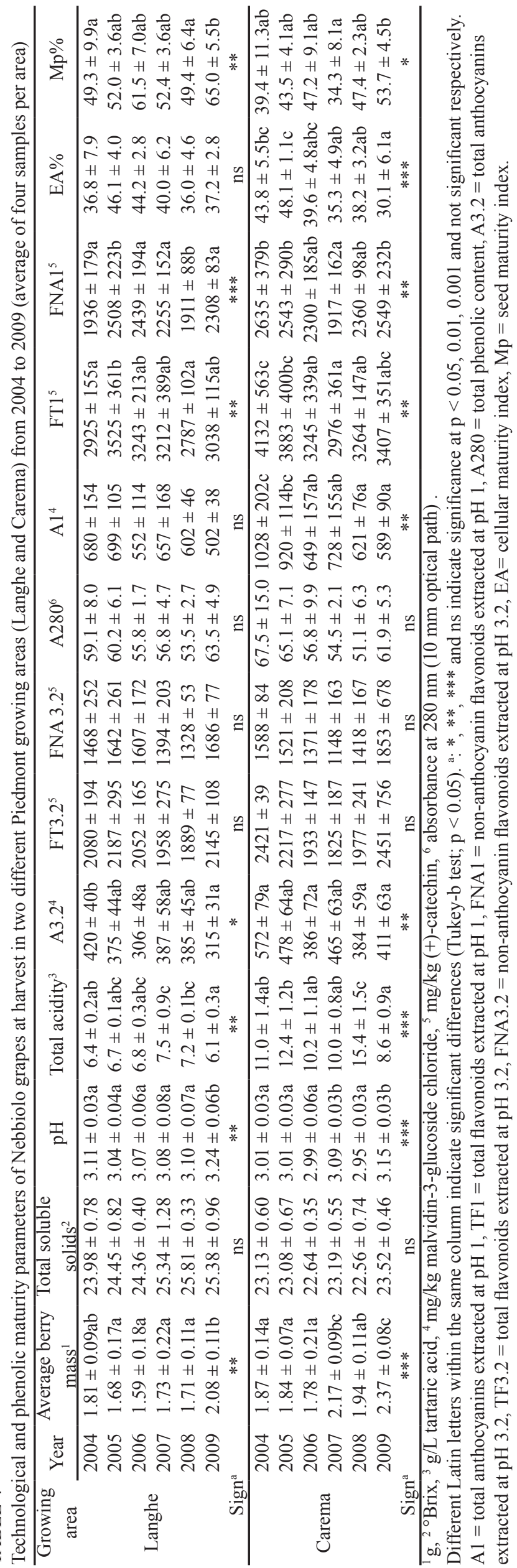


(Romero-Cascales et al., 2005; Ortega-Regules et al., 2008).

The box-plot of technological and phenolic parameters, including all the grapes sampled at harvest in the years 2004 to 2009 in the Langhe and Carema zones, is shown in Figures 1 and 2 respectively. In the Carema zone, most of grape berries showed very high total acidity as well as low $\mathrm{pH}$ and total soluble solids, typical values in musts from grapes grown in a cool climate. Furthermore, these values were significantly different from those of the Langhe grapes. Particularly, total acidity was significantly higher in the Carema zone for all vintages, with values exceeding $10 \mathrm{~g} / \mathrm{L}$, excepting for 2009 , which had a value of $8.6 \mathrm{~g} / \mathrm{L}$. The cooler climate of the Carema mountain area causes a retarding effect on grape maturation (Jackson \& Lombard, 1993). In accordance with the "Disciplinary of Production" of Carema wine, the production yield of the vineyards studied, in all the different years, amounted to between 7.2 and $8.0 \mathrm{t} / \mathrm{ha}$, the same as quantified in the Langhe area.

Generally, the average berry mass was higher in Carema grapes, but the differences were not always significant in all the years studied. In spite of Al being similar in the Langhe and Carema zones, a significantly higher A3.2 was obtained in the latter. When the phenolic maturity parameters were compared in Langhe and Carema grapes at harvest for each vintage, the differences found were partially significant, with FNA3.2, A280 and EA agreeing in all the years studied. Therefore, the anthocyanin extractability is confirmed as a varietal characteristic. The anthocyanin content was always higher in Carema grapes, ranging from 589 to $1028 \mathrm{mg} / \mathrm{kg}$ for A1, and from 384 to $572 \mathrm{mg} / \mathrm{kg}$ for A3.2. The cooler climate in the mountain area seems to increase the anthocyanin concentration in Carema grapes. In fact, Downey et al. (2006) reported that higher temperatures result in a decreased anthocyanin content, especially in Nebbiolo grapes (Chorti et al., 2010), which energised growers and researchers alike to examine mechanisms to manage the vineyard temperature. Therefore, lower temperatures can contribute to an improvement in the colour of Nebbiolo wines, and these compositional changes are of concern to an industry seeking economic sustainability. Nevertheless, a hotter climate can induce damage in berry skins, causing an increase in anthocyanin extractability (Lorrain et al., 2011).

The seasonal variability in the technological and phenolic maturity parameters obtained in the Langhe and Carema zones at harvest can also be observed in Figures 1 and 2. It was higher in Carema grapes, except for the average berry mass, total soluble solids and $\mathrm{pH}$ values.

All the technological and phenolic maturity parameters obtained in the Langhe and Carema zones at harvest are compared among years in Table 4 . The highest technological maturity corresponded to the grapes harvested in 2009 . The phenol richness of Nebbiolo grapes, particularly in compounds extractable at $\mathrm{pH} \mathrm{1,} \mathrm{was} \mathrm{significantly} \mathrm{higher}$ in 2005 for the Langhe zone and in 2004 and 2005 for the Carema zone. The higher values for EA were again associated with 2005, and the higher ones for Mp were obtained in 2009. In the Langhe and Carema zones, average berry mass, pH, total acidity, A3.2, FT1, FNA1 and Mp were seasonally dependent. Furthermore, A1 and EA were also influenced by the vintage in the Carema zone.
In accordance with other studies (Cadot et al., 2011), the synthesis of phenolic compounds is more dependent on the annual climate than on the growing area, because the climatic conditions before véraison determine the total amount of phenols found in skin cells. Although the climatic conditions of each year appear to have impacted more significantly on the anthocyanin extractability in the Carema zone, the seasonal differences in this index are less than in other phenol indices (González-Neves et al., 2010).

In most cases, A1, EA and $\mathrm{Mp}$ are within the range reported by Ribéreau-Gayon et al. (2004b), who consider values of 500 to $2000 \mathrm{mg} / \mathrm{L}, 70$ to $20 \%$ and 60 to $0 \%$, respectively, as the normal variation ranges. A1 and EA depend on the degree of ripeness and variety, while Mp also depends on the number of seeds per berry. Values for both EA and Mp lower than $30 \%$ are recommended by Zamora Marín (2003) for good phenolic maturity. Sometimes, the Mp values obtained were greater than those suggested and, therefore, long macerations are not advisable for Nebbiolo grapes.

\section{CONCLUSIONS}

Although some grape indices obtained at harvest were heavily influenced by seasonal variations, they agreed, with very few exceptions, for the grapes sampled weekly in the same growing area and year, as well as for the samples harvested in two growing areas at the same ripening stage and year. With a few exceptions, the environmental factors have more influence than the state of ripeness.

The technological interest lies in the fact that the final wine characteristics depend heavily on the phenolic composition of the grape berries. Furthermore, knowledge of the berry's susceptibility to release phenols would provide relevant information to improve the management of the maceration stage.

This work constitutes the first step in the creation of a historic databank for Nebbiolo grapes grown in Piedmont. The extension of this work to future vintages will permit an evaluation of the evolutionary trend in phenol composition and extractability over time, and an elucidation of the possible effect of climate change on the grape quality indices. No evident trend was observed in the six years studied.

\section{LITERATURE CITED}

Boulton, R., 2001. The copigmentation of anthocyanins and its role in the color of red wine: a critical review. Am. J. Enol. Vitic. 52, 67-87.

Cadot, Y., Chevalier, M. \& Barbeau, G., 2011. Evolution of the localisation and composition of phenolics in grape skin between veraison and maturity in relation to water availability and some climatic conditions. J. Sci. Food Agric. 91, 1963-1976.

Cagnasso, E., Rolle, L., Caudana, A. \& Gerbi, V., 2008. Relationship between grape phenolic maturity and red wine phenolic composition. Ital. J. Food Sci. 20, 365-381

Cheynier, V., Duenas-Paton, M., Salas, E., Maury, C., Souquet, J.M., Sarni-Manchado, P. \& Fulcrand, H., 2006. Structure and properties of wine pigments and tannins. Am. J. Enol. Vitic. 57, 298-305.

Cholet, C. \& Darné, G., 2004. Evolution of the contents in soluble phenolic compounds, in: proanthocyanic tanins and in anthocyanins of shot grape berries of Vitis vinifera L. during their development. J. Int. Sci. Vigne Vin 38, 171-180. 
Chorti, E., Guidoni, S., Ferrandino, A. \& Novello, V., 2010. Effect of different sunlight exposure levels on ripening and anthocyanin accumulation in Nebbiolo grapes. Am. J. Enol. Vitic. 61, 23-30.

De la Hera Orts, M.L., Martínez-Cutillas, A., López Roca, J.M., PérezPrieto, L.J. \& Gómez Plaza, E., 2005. Effect of deficit irrigation on anthocyanin content of Monastrell grapes and wines. J. Int. Sci. Vigne Vin 39, 47-55.

Di Stefano, R. \& Cravero, M.C., 1991. Metodi per lo studio dei polifenoli dell'uva. Riv. Vitic. Enol. 44, 2, 37-45.

Downey, M., Dokoozlian, N.K. \& Krstic, M.P., 2006. Cultural practice and environmental impacts on the flavonoid composition of grapes and wine: a review of recent research. Am. J. Enol. Vitic. 57, 257-268.

Failla, O., Mariani, L., Brancadoro, L., Minelli, R., Scienza, A., Murada, G. $\&$ Mancini, S., 2004. Spatial distribution of solar radiation and its effects on vine phenology and grape ripening in a alpine environment. Am. J. Enol. Vitic. 55, 128-138.

Fournand, D., Vicens, A., Sidhoum, L., Souquet, J.M., Moutounet, M. \& Cheynier, V., 2006. Accumulation and extractability of grape skin tannins and anthocyanins at different advanced physiological stages. J. Agric. Food Chem. 54, 7331-7338.

Fulcrand, H., Duenas, M., Salas, E. \& Cheynier, V., 2006. Phenolic reactions during winemaking and aging. Am. J. Enol. Vitic. 57, 289-297.

Glories, Y. \& Augustin, M., 1993. Maturité phénolique du raisin, conséquences technologiques: applications aux millésimes 1991 et 1992. In: Actes du Colloque Journée Technique du CIVB, CIVB, Bordeaux. pp. 56-61.

Glories, Y., 1999. La maturità fenolica delle uve: Primo parametro da controllare per una corretta viníficazione in rosso. Vignevini 3, 46-50.

González-Neves, G., Gil, G. \& Barreiro, L., 2008. Influence of grape variety on the extraction of anthocyanins during the fermentation on skins. Eur. Food Res. Technol. 226, 1349-1355.

González-Neves, G., Gil, G. \& Ferrer, M., 2002. Effect of different vineyard treatments on the phenolic contents in Tannat (Vitis vinifera L.) grapes and their respective wines. Food Sci. Technol. Int. 8, 315-317.

González-Neves, G., Gil, G., Ferrer, M., Darwin, C., Balado, J., Bochicchio, R., Gatto, G. \& Tessore, A., 2010. Prediction of the colour and polyphenolic composition of the young red wines from the phenolic potential of the grapes. Int. J. Food Sci. Technol. 45, 1843-1851.

Guidoni, S., Ferrandino, A. \& Novello, V., 2008. Effects of seasonal and agronomical practices on skin anthocyanin profile of Nebbiolo grapes. Am. J. Enol. Vitic. 59, 22-29.

Jackson, D.I. \& Lombard, P.B., 1993. Environmental and management practices affecting grape composition and wine quality. A review. Am. J. Vitic. Enol. 44, 409-430.

Kennedy, J.A., Matthews, M.A. \& Waterhouse, A.L., 2000. Changes in grape seed polyphenols during fruit ripening. Phytochemistry 55, 77-85.

Kontoudakis, N., Esteruelas, M., Fort, F., Canals, J.M. \& Zamora, F. 2010. Comparison of methods for estimating phenolic maturity in grapes: correlations between predicted and obtained parameters. Anal. Chim. Acta $660,127-133$

Lorrain, B., Chira, K. \& Teissedre, P.-L., 2011. Phenolic composition of Merlot and Cabernet-Sauvignon grapes from Bordeaux vineyard for the 2009-vintage: comparison to 2006, 2007 and 2008 vintages. Food Chem. 126, 1991-1999.

Mateus, N., Machado, J.M. \& De Freitas, V., 2002. Development changes of anthocyanins in Vitis vinifera grapes grown in the Douro Valley and concentration in respective wines. J. Sci. Food Agric. 82, 1689-1695.
Mattivi, F., Guzzon, R., Vrhovsek, U., Stefanini, M. \& Velasco, R., 2006. Metabolite profiling of grape: flavonols and anthocyanins. J. Agric. Food Chem. 54, 7692-7702.

Mattivi, F., Vrhovsek, U., Masuero, D. \& Trainotti, D., 2009. Differences in the amount and structure of extractable skin and seed tannins amongst red grape varieties. Aust. J. Grape Wine Res. 15, 27-35.

Navarro, S., León, M., Roca-Pérez, L., Boluda, R., García-Ferriz, L., PérezBermúdez, P. \& Gavidia, I., 2008. Characterisation of Bobal and Crujidera grape cultivars, in comparison with Tempranillo and Cabernet Sauvignon: evolution of leaf macronutrients and berry composition during grape ripening. Food Chem. 108, 182-190.

OIV, 2008. Recueil international des méthodes d'analyse des vins et des moûts. Paris, France.

Ortega-Regules, A., Romero-Cascales, I., Ros-García, J.M., López-Roca, J.M. \& Gómez-Plaza, E., 2006. A first approach towards the relationship between grape skin cell-wall composition and anthocyanin extractability. Anal. Chim. Acta 563, 26-32.

Ortega-Regules, A., Ros-García, J., Bautista-Ortín, A., López-Roca, J. \& Gómez-Plaza, E., 2008. Changes in skin cell wall composition during the maturation of four premium wine grape varieties. J. Sci. Food Agric. 88, 420-428.

Revilla, E., García-Beneytez, E. \& Cabello, F., 2009. Anthocyanin fingerprint of clones of Tempranillo grapes and wines made with them. Aust. J. Grape Wine Res. 15, 70-78.

Ribéreau-Gayon, P., 1970. Le dosage des composes phénoliques totaux dans le vins rouges. Chim. Anal. 52, 627-631.

Ribéreau-Gayon, P., Glories, Y., Maujean, A. \& Dubourdieu, D., 2004a. In: Traité d'oenologie. 1 Microbiologie du vin - Vinification, vol. 1. Dunod, Paris.

Ribéreau-Gayon, P., Glories, Y., Maujean, A. \& Dubourdieu, D., 2004b. In: Traité d'oenologie. 2 Chemie du vin - Stabilisation et traitements, vol. 2. Dunod, Paris.

Río Segade, S., Soto Vázquez, E. \& Díaz Losada, E., 2008. Influence of ripeness grade on accumulation and extractability of grape skin anthocyanins in different cultivars. J. Food Comp. Anal. 21, 599-607.

Romero-Cascales, I., Ortega-Regules, A., López-Roca, J.M., FernándezFernández, J.I. \& Gómez-Plaza, E., 2005. Differences in anthocyanin extractability from grapes to wines according to variety. Am. J. Enol. Vitic. $56,212-219$.

Ryan, J.M. \& Revilla, E., 2003. Anthocyanin composition of Cabernet Sauvignon and Tempranillo grapes at different stages of ripening. J. Agric. Food Chem. 51, 3372-3378.

Sacchi, K.L., Bisson, L.F. \& Adams, D.O., 2005. A review of the effect of winemaking techniques on phenolic extraction in red wines. Am. J. Enol. Vitic. 56, 197-206.

Saint-Cricq, N., Vivas, N. \& Glories, Y., 1998a. Maturation phénolique des raisins rouges relation avec la qualité des vins. Comparaison des cépages Merlot et Tempranillo. Progr. Agric. Vitic. 115, 306-318.

Saint-Cricq, N., Vivas, N. \& Glories, Y., 1998b. Maturité phénolique: définition et contrôle. Rev. Fr. Oenol. 173, 22-25.

Torchio, F., Cagnasso, E., Gerbi, V. \& Rolle, L., 2010. Mechanical properties, phenolic composition and extractability indices of Barbera grapes of different soluble solids contents from several growing areas. Anal. Chim. Acta 660, 183-189.

Vacca, V., Del Caro, A., Milella, G.G. \& Nieddu, G., 2009. Preliminary characterisation of Sardinian red grape cultivars (Vitis vinifera L.) according to their phenolic potential. S. Afr. J. Enol. Vitic. 30, 93-100. 
Vidal, S., Cartalade, D., Souquet, J.M., Fulcrand, H. \& Cheynier, V., 2002. Changes in proanthocyanidin chain length in winelike model solutions. J. Agric. Food Chem. 50, 2261-2266.

Vidal, S., Francis, L., Noble, A., Kwiatkowski, M., Cheynier, V. \& Waters, E., 2004. Taste and mouth-feel properties of different types of tannin-like polyphenolic compounds and anthocyanins in wine. Anal. Chim. Acta 513, $57-65$
Zamora Marín, F., 2003. Elaboración y crianza del vino tinto: Aspectos científicos y prácticos. Mundi-Prensa, Madrid.

Zanoni, B., Siliani, S., Canuti, V., Rosi, I. \& Bertuccioli, M., 2010. A kinetic study on extraction and transformation phenomena of phenolic compounds during red wine fermentation. Int. J. Food Sci. Technol. 45, 2080-2088. 